\title{
Plant-Soil Feedback In Camellia Oleifera And Mixed Gardenia Jasminoides Ellis-Camellia Oleifera Stands Determined By Soil Bacterial Community Analysis
}

\section{Yun Wang}

Central South University of Forestry and Technology

\section{Peng Xie}

Hunan University of Arts and Science

Jiyun She (D297262359@qq.com )

Central South University of Forestry and Technology https://orcid.org/0000-0003-0071-1948

Aihua Deng

Hunan University of Arts and Science

Shaogang Fan

Hunan Agricultural University

\section{Research Article}

Keywords: Camellia oleifera, Microbial communities, Physicochemical property, Forest type

Posted Date: September 14th, 2021

DOI: https://doi.org/10.21203/rs.3.rs-849971/v1

License: (c) (1) This work is licensed under a Creative Commons Attribution 4.0 International License.

Read Full License 


\section{Abstract}

Purpose: Little is known regarding the combined impact of plant and soil traits on the soil bacterial community. Herein, we assessed physical and chemical properties along with bacterial community structure in soils sampled at different depths $(0-20 \mathrm{~cm}, 20-40 \mathrm{~cm}$, and $40-60 \mathrm{~cm})$ and slope positions (peak, hillside, and bottom), in Camellia oleifera monoculture and mixed Gardenia jasminoides-Camellia oleifera stands.

Methods: Soil physicochemical characteristics were determined using standard methods. The composition of soil bacterial communities was evaluated using high-throughput sequencing of the $16 \mathrm{~S}$ rRNA gene.

Results: Soil organic carbon, humus, and total organic contents were higher in $G$. jasminoides $+C$. oleifera low-yielding forest than in other stands, however, the $\mathrm{NH}_{4}{ }^{+} \mathrm{N}$ levels were significantly lower than that in monoculture. The slope position did not greatly influence soil physical and chemical properties. The dominant bacteria were Proteobacteria, Chloroflexi, Acidobacteria, and Actinobacteria. The alpha and beta diversity and abundance of soil bacterial community were higher in intercropping systems than in monoculture systems. Potassium and nitrogen levels and $\mathrm{pH}$ significantly affected the soil microbial community composition. Correlation analysis revealed that alkaline hydrolysable nitrogen and $\mathrm{pH}$ were significantly correlated with the input of plant-associated organic matter and dynamic changes of keystone taxa.

Conclusion: G. jasminoides improved the physicochemical characteristics of $C$. oleifera low-yielding soil and greatly affected the soil bacterial community, further improving the soil microecological environment. Therefore, this specific intercropping system is an effective strategy for improving soil health.

\section{Introduction}

Camellia oleifera, an evergreen tree belonging to the Theaceae family and originating in China, is a wellknown woody oil tree species used to produce Camellia seed oil. The Hunan Province is an important production region of $C$. oleifera in China. A centralised and continuous distribution pattern has laid the foundation for the industrialisation and large-scale operations of $C$. oleifera forest.

The soil is one of the most important environmental factors that impacts plant physiology; its quality affects the size and stability of $C$. oleifera yield. Soil nutrient content and microbial communities are crucial components of every ecosystem and are important drivers of global biogeochemistry. Soil bacterial community composition is strongly linked to land use, which can be used to determine the type of land use accurately. It can also be used to differentiate sites grouped by key physicochemical properties (Hermans et al. 2020).

As the main source of nutrients for plant growth, the nutritional status of the soil is one of the key factors directly influencing plant growth and development (Xiao and He 2019). Soil microorganisms are a key 
index of soil fertility and play major roles in soil productivity and fertility, including organic matter decomposition, nutrient cycling, and soil aggregate formation (Ding et al. 2017; Müller et al. 2016; Nacke et al. 2016; Six et al. 2004; Zhalnina et al. 2015).

Recent studies on typical forests have revealed that land use exerts a long-term effect on the soil microbiota structure and diversity (Goss-Souza et al. 2017). Soil microbial characteristics are not only controlled by changes in the moisture and temperature and driven by seasonal fluctuations, but are also closely associated with the soil chemical characteristics (Jiao et al. 2018) and those of the forest itself, the forestland habitat, and the rhythm of forest growth and development. A moderate growth of soil microorganisms may promote the transformation and storage of soil nutrients in the rhizosphere, affect physical and chemical properties of the soil, and change hormone distribution in the rhizosphere. Metabolites produced by soil microorganisms can be used as a source of nutrients for plant growth, affecting plant growth and development, succession, and community diversity (Dunn et al. 2006; van der Heijden et al. 2006). The difference in the soil physico-structural characteristics under different vegetation management measures in different forest types is bound to affect soil bacterial diversity and community structure, and further affect the evolution of soil physico-structural properties and their ecological functions. Hermans et al. (2017) has demonstrated the ability of key bacterial taxonomic groups to reflect the impact of specific anthropogenic activities and have provided strong evidence of the largely untapped potential of microorganisms to indicate the condition of soil.

The main $C$. oleifera growing areas in China are primarily with acid red soil and yellow soil in the southern region. The red soil has poor breathability, low organic matter content, and is relatively nutrient-poor, affecting plant growth. Compound fertiliser, $C$. oleifera special fertiliser, and bioorganic fertiliser greatly promote the soil nitrogen content, microbial community abundance, and biological activity, as well as plant yield. Furthermore, the use of biological agents instead of chemical fertilisers reduces environmental pollution and increases the yield of C. oleifera (Wu et al. 2019).

In the red soil hilly region in southern China, $C$. oleifera helps to enhance and maintain soil fertility and the ecological quality of planted tree species (Tu et al. 2019). However, considering the long growth cycle and low or even no gains early in growing of economic forests, identification of a novel scientific forestry production approach is of utmost importance. Agroforestry management is an emerging land use and management method to address this problem and has attracted significant global attention. Accordingly, intercropping $C$. oleifera with peanut improves the soil porosity, conductivity, and the rhizosphere bacterial and fungal populations compared with C. oleifera monoculture (Lu et al. 2019; Kroon et al. 2019; Liu et al. 2020). Past studies on plant-soil interactions have revealed many advantages of intercropping, such as improved yield, accretion, and decomposition of organic matter, enhanced iron nutrition and phosphorus availability, etc. In mixed forest stands, the microbial community diversity has increased and effectively inhibits soil erosion, greatly improving the microclimate environment under the forest floor, increasing crop yields, and contributing to the sustainable development of agriculture and forestry (Dollinger and Jose 2018; Mosquera-Losada et al. 2018). Intercropping also improves forest productivity, provides important non-economic benefits (e.g., society and environment benefits), and increases farm yield and 
agricultural income, which helps farmers to establish resists each livelihood impact the adaptive faculty (Li et al. 2019; Quandt et al. 2019).

C. oleifera is an important oil-yielding woody plant, whose growth can be promoted by changing its soil microbial community (Zhang et al. 2020). Studies on soil microbial communities in C. oleifera have suggested that different climates, plantations, and site morphological differences, such as soil depth, can influence the microbial community composition in C. oleifera forestry (Tobias-Hünefeldt et al. 2019). However, the structural composition of bacterial microbiome in the $C$. oleifera intercropping system remains to be characterised. Hence, studying different tea-oil forests can help to expand our understanding of the fertility and soil development of these different forests, explain the role of microorganisms in the growth and development of tea-oil forest vegetation, and develop effective afforestation and forestry measures to improve the existing tea-oil forest structure and promote the sustainable development of tea-oil forests.

In the current study, we analysed different forest types of $C$. oleifera at Tangjiapu (Dingcheng District, China) to determine differences in the structure of soil microbiomes in different forests. Specifically, we focused on $C$. oleifera new afforestation, Gardenia jasminoides with $C$. oleifera new afforestation, $G$. jasminoides with $C$. oleifera low-yielding forest, and $C$. oleifera low-yielding forest. We also analysed correlations between the forest type, soil, and soil microorganisms to determine the mode of planting most suitable for $C$. oleifera. The study serves as reference for efficient and sustainable management of C. oleifera low-yielding forest plantations.

\section{Materials And Methods}

\section{Site description}

The experimental site was a forest farm in Tangjiapu (Dingcheng District, Changde, Hunan Province, China). The climate is subtropical monsoon, with the mean annual total rainfall of $1,200-1,900 \mathrm{~mm}$. The mean annual temperature is $16.7^{\circ} \mathrm{C}$. The soil at the experimental site is quaternary red clay with $\mathrm{pH}$ of 5 .

\section{Experimental design}

For the study, 36 soil samples were randomly collected from different forest types (NA, C. oleifera new afforestation; GNA, G. jasminoides + C. oleifera new afforestation; GLF, G. jasminoides + C. oleifera lowyielding forest; and LF, C. oleifera low-yielding forest) in April 2019. On each block, a typical topographic profile in the south to north direction was selected, and the sampling plots were set at three slope positions: bottom, hillside (middle), and peak. Stratified sampling was performed at different depths (0$20 \mathrm{~cm}, 20-40 \mathrm{~cm}$, and $40-60 \mathrm{~cm}$ ) along slope positions, and three replicate plots were selected. Collected samples were immediately quick-frozen in liquid nitrogen, placed in a sterile plastic bag, labelled, transferred to the laboratory in a portable refrigerator on dry ice, and stored at $-80^{\circ} \mathrm{C}$ before microbial community analysis.

\section{Chemical and physical soil analysis}


Soil pH was measured using a pH meter in a soil:water suspension (1:5 w/v), after shaking for $30 \mathrm{~min}$. Soil organic carbon (SOC) and soil organic matter ( $\mathrm{SOM}$ ) were determined by using $\mathrm{K}_{2} \mathrm{Cr}_{2} \mathrm{O}_{7}-\mathrm{H}_{2} \mathrm{SO}_{4}$ oxidation-reduction colorimetric method (Schulz 2002). Soil total nitrogen (TN) was measured by Kjeldahl digestion method (Krishnamoorthy 1982). The total organic carbon (TOC) of the soil was measured using a TOC analyser (Elementar GmbH, Langenselbold, Germany). The humus content (HC), $\mathrm{TN}$, total carbon $(\mathrm{TC})$, nitrate nitrogen $\left(\mathrm{NO}_{3}-\mathrm{N}\right)$, nitrite nitrogen $\left(\mathrm{NO}_{2}-\mathrm{N}\right)$, and ammonium nitrogen $\left(\mathrm{NH}_{4}{ }^{+}-\mathrm{N}\right)$ levels were determined using colorimetry (Wang 2011). Measurements of available phosphorus (AP) and available potassium (AK) were performed using the methods described by Mitchell et al. (2010). Soil available nitrogen (AN) was determined by diffusion methods (Khan 1997).

\section{Soil microbial community}

Microbial community diversity and composition were assessed by amplification of the 16S rRNA gene as described by Prober et al. (2015). Soil samples were processed using a MOBIO PowerSoil@ kit. The DNA quality was confirmed by $1 \%$ agarose gel electrophoresis. The extracted DNA samples were selected and used to conduct microbial community analysis by polymerase chain reaction (PCR) using the following 16S rDNA primers: forward (5- GTGC AGCMGC $G C G G$ - 3) and reverse (5 - $\mathbb{C} G T C \forall$ T $C M$ T TRAG T T - 3) (Lane 1991). PCR reactions were conducted by TransGen AP22102: TransStart Fastpfu DNA Polymerase. The PCR products were extracted from a $2 \%$ agarose gel and further purified using the AxyPrep DNA Gel Extraction Kit (Axygen Biosciences, Union City, CA, USA) and eluted in Tris buffer. Products were quantified using QuantiFluor-ST (Promega, Madison, USA). Purified amplicons were then pooled in equimolar concentrations and paired-end sequenced $(2 \times 300)$ using the Illumina MiSeq platform (Illumina, San Diego, CA, USA) according to standard protocols of Shanghai Majorbio Bio-pharm Technology Co., Ltd.

\section{Data processing}

Similarities and differences between samples were based on operational taxonomic unit (OTU) clustering, and representative sequences in OTU clusters were obtained. The most abundant sequences were selected as the representative OTUs and used in various OTU analyses. Soil bacterial alpha diversity (observed OTUs and Chao, Shannon, and Simpson indices) was calculated after randomly subsampling sequences to an equal number. To analyse species turnover, we calculated the Bray-Curtis dissimilarity in the same subplot at different forests type, slope position, and depth. The principal coordinate analysis (PCoA) of $\beta$-diversity was calculated based on the Bray-Curtis algorithm. The data were analysed using the free online platform of Majorbio Cloud Platform (www.majorbio.com).

\section{Statistical analysis}

Paired-end reads of the 16S rRNA gene were assembled using Flash (v1.2.11) (https://ccb.jhu.edu/software/FLASH/index.shtml) to obtain raw tags. Relative abundance taxonomic summaries, beta diversity, and rarefactions were examined with QIIME (v1.9.1) (http://qiime.org/install/index.html). The OTU clustering of sequences was performed with the UPARSE (v7.0.1090) (http://www.drive5.com/uparse/). Taxonomic classification was conducted using the 
ribosomal database project classifier (v2.11) (https://sourceforge.net/projects/rdp-classifier/).

Concatenated sequences were detected using USEARCH (v7.0) (http://www.drive5.com/usearch/). Alpha and beta diversity estimates were calculated by MOTHUR (v1.30.2)

(https://www.mothur.org/wiki/Download_mothur).

\section{Results}

\section{Physical and chemical analysis of soil samples}

Soil physicochemical properties that could be directly influenced by the soil depth and forest type are shown in Fig. 1 and Tables 1 and 2. There were no significant differences in the five physical indicators evaluated (soil moisture content [SMC], pH, electric conductivity [EC], total dissolved solids [TDS], and specific soil weight [GS]) in soils at different depths $(P>0.05$; Fig. 1). In contrast, there were significant differences in soil EC between the hillside and bottom locations $(P<0.05)$. For different forest types, soil EC was significantly higher in GNA than in GLF; that in NA was highly significantly higher than that in GLF; and that in LF was highly significantly higher than that in GNA and GLF. Hence, intercropping may cause fluctuations in the soil EC and may affect soil physicochemical properties. 
Table 1

Effect of depth, slope position, and forest type on the soil nutrients (1)

\begin{tabular}{|c|c|c|c|c|c|c|}
\hline \multicolumn{2}{|l|}{$\begin{array}{l}\text { Sampling } \\
\text { condition }\end{array}$} & \multirow{2}{*}{$\begin{array}{l}\text { TOC } \\
\left(\mathbf{g} \cdot \mathrm{kg}^{-1}\right) \\
12.19 \pm \\
1.13^{\mathrm{Aa}}\end{array}$} & \multirow{2}{*}{$\begin{array}{l}\text { SOM } \\
\begin{array}{l}\text { (\%) } \\
0.02 \pm \\
0.00^{\mathrm{Aa}}\end{array}\end{array}$} & \multirow{2}{*}{$\begin{array}{l}\mathrm{HC} \\
\left(\mathrm{mg} \cdot \mathrm{kg}^{-1}\right) \\
5.36 \pm \\
0.87^{\mathrm{Aa}}\end{array}$} & \multirow{2}{*}{$\begin{array}{l}\text { TN } \\
(\%) \\
0.18 \pm \\
0.01^{\mathrm{Aa} a}\end{array}$} & \multirow{2}{*}{$\begin{array}{l}\text { TC } \\
(\%) \\
1.51 \pm \\
0.15^{\mathrm{Aa}}\end{array}$} \\
\hline Depth (cm) & $0-20$ & & & & & \\
\hline & $20-40$ & $\begin{array}{l}9.50 \pm \\
0.72^{\mathrm{ABb}}\end{array}$ & $\begin{array}{l}0.02 \pm \\
0.00^{\mathrm{Ab}}\end{array}$ & $\begin{array}{l}4.58 \pm \\
0.62^{\mathrm{Aa}}\end{array}$ & $\begin{array}{l}0.15 \pm \\
0.01^{A B} \mathrm{~b}\end{array}$ & $\begin{array}{l}1.06 \pm \\
0.08^{\mathrm{Bb}}\end{array}$ \\
\hline & $40-60$ & $\begin{array}{l}8.52 \pm \\
0.85^{\mathrm{Bb}}\end{array}$ & $\begin{array}{l}0.01 \pm \\
0.00^{\mathrm{Ab}}\end{array}$ & $\begin{array}{l}4.99 \pm \\
0.62^{\mathrm{Aa}}\end{array}$ & $\begin{array}{l}0.14 \pm \\
0.01^{\mathrm{Bb}}\end{array}$ & $\begin{array}{l}1.01 \pm \\
0.11^{\mathrm{Bb}}\end{array}$ \\
\hline \multirow[t]{3}{*}{ Slope position } & Peak & $\begin{array}{l}10.76 \pm \\
1.04^{\mathrm{Aa}}\end{array}$ & $\begin{array}{l}0.01 \pm \\
0.00^{\mathrm{Aa}}\end{array}$ & $\begin{array}{l}4.76 \pm \\
1.19^{\mathrm{Aa}}\end{array}$ & $\begin{array}{l}0.16 \pm \\
0.01^{\mathrm{Aa}}\end{array}$ & $\begin{array}{l}1.12 \pm \\
0.11^{\mathrm{Aa}}\end{array}$ \\
\hline & Hillside & $\begin{array}{l}10.29 \pm \\
1.14^{\mathrm{Aa}}\end{array}$ & $\begin{array}{l}0.00 \pm \\
0.00^{\mathrm{Aa}}\end{array}$ & $\begin{array}{l}5.54 \pm \\
0.83^{\mathrm{Aa}}\end{array}$ & $\begin{array}{l}0.15 \pm \\
0.01^{\mathrm{Aa}}\end{array}$ & $\begin{array}{l}1.25 \pm \\
0.11^{\mathrm{Aa}}\end{array}$ \\
\hline & Bottom & $\begin{array}{l}9.38 \pm \\
0.67^{\mathrm{Aa}}\end{array}$ & $\begin{array}{l}0.01 \pm \\
0.00^{\mathrm{Aa}}\end{array}$ & $\begin{array}{l}4.76 \pm \\
0.78^{\mathrm{Aa}}\end{array}$ & $\begin{array}{l}0.15 \pm \\
0.01^{\mathrm{Aa}}\end{array}$ & $\begin{array}{l}1.20 \pm \\
0.17^{\mathrm{Aa}}\end{array}$ \\
\hline \multirow[t]{4}{*}{ Forest Type } & NA & $\begin{array}{l}9.76 \pm \\
1.61^{\mathrm{ABb}}\end{array}$ & $\begin{array}{l}0.02 \pm \\
0.00^{\mathrm{ABb}}\end{array}$ & $\begin{array}{l}4.17 \pm \\
0.96^{\mathrm{Bb}}\end{array}$ & $\begin{array}{l}0.15 \pm \\
0.01^{\mathrm{Bb}}\end{array}$ & $\begin{array}{l}1.10 \pm \\
0.18^{\mathrm{Bb}}\end{array}$ \\
\hline & GNA & $\begin{array}{l}8.26 \pm \\
0.42^{\mathrm{Bb}}\end{array}$ & $\begin{array}{l}0.01 \pm \\
0.00^{\mathrm{Bb}}\end{array}$ & $\begin{array}{l}4.05 \pm \\
0.33^{\mathrm{Bb}}\end{array}$ & $\begin{array}{l}0.14 \pm \\
0.00^{\mathrm{Bb}}\end{array}$ & $\begin{array}{l}0.95 \pm \\
0.05^{\mathrm{Bb}}\end{array}$ \\
\hline & LF & $\begin{array}{l}9.923 \pm \\
0.84^{\mathrm{ABb}}\end{array}$ & $\begin{array}{l}0.02 \pm \\
0.00^{\mathrm{ABb}}\end{array}$ & $\begin{array}{l}3.77 \pm \\
0.25^{\mathrm{Bb}}\end{array}$ & $\begin{array}{l}0.15 \pm \\
0.01^{\mathrm{ABb}}\end{array}$ & $\begin{array}{l}1.10 \pm \\
0.09^{\mathrm{Bb}}\end{array}$ \\
\hline & GLF & $\begin{array}{l}13.01 \pm \\
1.05^{\mathrm{Aa}}\end{array}$ & $\begin{array}{l}0.02 \pm \\
0.00^{\mathrm{ABb}}\end{array}$ & $\begin{array}{l}7.80 \pm \\
0.69^{\mathrm{Aa}}\end{array}$ & $\begin{array}{l}0.19 \pm \\
0.01^{\mathrm{Aa}}\end{array}$ & $\begin{array}{l}1.62 \pm \\
0.16^{\mathrm{Aa}}\end{array}$ \\
\hline \multicolumn{7}{|c|}{$\begin{array}{l}\text { Data are presented as mean } \pm S D(n=9 \text { or } 12) \text {. Different lowercase letters in the same column } \\
\text { represent significance differences at } P \leq 0.05 \text { and different uppercase letters represent significant } \\
\text { differences at } P \leq 0.01 \text {. The one-way ANOVA was used for statistical test. NA, Camellia oleifera new } \\
\text { afforestation; GLF, Gardenia jasminoides in a C. Oleifera low-yielding forest; LF, C. oleifera low-yielding } \\
\text { forest; GNA, G. jasminoides in C. oleifera new afforestation. TOC, total organic content, HC, humus } \\
\text { content; SOM, soil organic matter; TN, soil total nitrogen; TC, soil total carbon }\end{array}$} \\
\hline
\end{tabular}


Table 2

Effect of depth, slope position, and forest type on soil nutrient content (2)

\begin{tabular}{|c|c|c|c|c|c|c|c|}
\hline $\begin{array}{l}\text { Sampling } \\
\text { condition }\end{array}$ & & $\begin{array}{l}\mathrm{NH}_{4}^{+}-\mathrm{N} \\
\left(\mathrm{mg} \cdot \mathrm{kg}^{-}\right. \\
\left.{ }^{1}\right)\end{array}$ & $\begin{array}{l}\mathrm{NO}_{3}-\mathrm{N} \\
\left(\mathrm{mg} \cdot \mathrm{kg}^{-}\right. \\
\left.{ }^{1}\right)\end{array}$ & $\begin{array}{l}\mathrm{NO}_{2}-\mathrm{N} \\
\left(\mathrm{g} \cdot \mathrm{kg}^{-1}\right)\end{array}$ & $\begin{array}{l}\text { AN } \\
\left(\mathrm{mg} \cdot \mathrm{kg}^{-1}\right)\end{array}$ & $\begin{array}{l}\text { AK } \\
\left(\mathrm{mg} \cdot \mathrm{kg}^{-}\right. \\
\left.{ }^{1}\right)\end{array}$ & $\begin{array}{l}\text { AP } \\
\left(\mathrm{mg} \cdot \mathrm{kg}^{-1}\right)\end{array}$ \\
\hline \multirow[t]{3}{*}{ Depth (cm) } & $0-20$ & $\begin{array}{l}7.18 \pm \\
1.38^{\mathrm{Aa}}\end{array}$ & $\begin{array}{l}4.27 \pm \\
1.35^{\mathrm{Aa}}\end{array}$ & $\begin{array}{l}1.26 \pm \\
0.12^{\mathrm{Aa}}\end{array}$ & $\begin{array}{l}99.25 \pm \\
9.58^{A a}\end{array}$ & $\begin{array}{l}5.04 \pm \\
0.89^{\mathrm{Aa}}\end{array}$ & $\begin{array}{l}1.80 \pm \\
0.27^{\mathrm{Aa}}\end{array}$ \\
\hline & $20-40$ & $\begin{array}{l}4.76 \pm \\
1.1 A^{\mathrm{Bab}}\end{array}$ & $\begin{array}{l}2.62 \pm \\
0.96^{\mathrm{Aa}}\end{array}$ & $\begin{array}{l}1.13 \pm \\
0.07^{\text {Aab }}\end{array}$ & $\begin{array}{l}81.20 \pm \\
5.31^{\mathrm{ABab}}\end{array}$ & $\begin{array}{l}4.62 \pm \\
0.98^{\mathrm{Aa}}\end{array}$ & $\begin{array}{l}0.60 \pm \\
0.15^{\mathrm{Bb}}\end{array}$ \\
\hline & $40-60$ & $\begin{array}{l}3.124 \pm \\
0.32 \mathrm{Bb}\end{array}$ & $\begin{array}{l}3.08 \pm \\
0.49^{\mathrm{Aa}}\end{array}$ & $\begin{array}{l}0.95 \pm \\
0.07^{A b}\end{array}$ & $\begin{array}{l}74.39 \pm \\
4.41^{\mathrm{Bb}}\end{array}$ & $\begin{array}{l}4.11 \pm \\
0.44^{\mathrm{Aa}}\end{array}$ & $\begin{array}{l}0.45 \pm \\
0.12^{\mathrm{Bb}}\end{array}$ \\
\hline \multirow[t]{3}{*}{$\begin{array}{l}\text { Slope } \\
\text { position }\end{array}$} & Peak & $\begin{array}{l}6.51 \pm \\
1.20^{\mathrm{Aa}}\end{array}$ & $\begin{array}{l}3.07 \pm \\
0.54^{\mathrm{Aa}}\end{array}$ & $\begin{array}{l}1.20 \pm \\
0.11^{\mathrm{Aa}}\end{array}$ & $\begin{array}{l}89.88 \pm \\
7.26^{\mathrm{Aa}}\end{array}$ & $\begin{array}{l}4.69 \pm \\
0.66^{\mathrm{Aa}}\end{array}$ & $\begin{array}{l}0.69 \pm \\
0.13^{\mathrm{Aa}}\end{array}$ \\
\hline & Hillside & $\begin{array}{l}3.99 \pm \\
0.83^{\mathrm{Aa}}\end{array}$ & $\begin{array}{l}4.79 \pm \\
1.39^{\mathrm{Aa}}\end{array}$ & $\begin{array}{l}1.19 \pm \\
0.11^{\mathrm{Aa}}\end{array}$ & $\begin{array}{l}84.99 \pm \\
4.58^{A a}\end{array}$ & $\begin{array}{l}4.87 \pm \\
0.93^{\mathrm{Aa}}\end{array}$ & $\begin{array}{l}1.05 \pm \\
0.32^{\mathrm{Aa}}\end{array}$ \\
\hline & Bottom & $\begin{array}{l}4.08 \pm \\
0.82^{\mathrm{Aa}}\end{array}$ & $\begin{array}{l}2.96 \pm \\
0.36^{\mathrm{Aa}}\end{array}$ & $\begin{array}{l}0.99 \pm \\
0.09^{\mathrm{Aa}}\end{array}$ & $\begin{array}{l}77.24 \pm \\
7.72^{\mathrm{Aa}}\end{array}$ & $\begin{array}{l}3.95 \pm \\
0.60^{\mathrm{Aa}}\end{array}$ & $\begin{array}{l}1.23 \pm \\
0.30^{\mathrm{Aa}}\end{array}$ \\
\hline \multirow[t]{4}{*}{ Forest type } & NA & $\begin{array}{l}6.46 \pm \\
1.75^{\mathrm{Aab}}\end{array}$ & $\begin{array}{l}2.76 \pm \\
0.39^{\mathrm{Bb}}\end{array}$ & $\begin{array}{l}1.27 \pm \\
0.13^{\mathrm{Aa}}\end{array}$ & $\begin{array}{l}90.33 \pm \\
10.50^{\mathrm{Aa}}\end{array}$ & $\begin{array}{l}7.53 \pm \\
0.93^{\mathrm{Aa}}\end{array}$ & $\begin{array}{l}0.25 \pm \\
0.11^{\mathrm{Bb}}\end{array}$ \\
\hline & GNA & $\begin{array}{l}2.23 \pm \\
0.33^{\mathrm{BC}}\end{array}$ & $\begin{array}{l}1.82 \pm \\
0.32^{\mathrm{Bb}}\end{array}$ & $\begin{array}{l}1.25 \pm \\
0.19^{\mathrm{Aa}}\end{array}$ & $\begin{array}{l}84.46 \pm \\
5.26^{A a b}\end{array}$ & $\begin{array}{l}2.72 \pm \\
0.35^{\mathrm{Bb}}\end{array}$ & $\begin{array}{l}0.84 \pm \\
0.27^{\mathrm{ABab}}\end{array}$ \\
\hline & LF & $\begin{array}{l}3.76 \pm \\
0.82^{\mathrm{ABbc}}\end{array}$ & $\begin{array}{l}7.39 \pm \\
1.52^{\mathrm{Aa}}\end{array}$ & $\begin{array}{l}0.95 \pm \\
0.08^{\mathrm{Aa}}\end{array}$ & $\begin{array}{l}65.59 \pm \\
3.88^{\mathrm{Ab}}\end{array}$ & $\begin{array}{l}3.51 \pm \\
0.23^{\mathrm{Bb}}\end{array}$ & $\begin{array}{l}1.25 \pm \\
0.13^{\mathrm{ABa}}\end{array}$ \\
\hline & GLF & $\begin{array}{l}6.98 \pm \\
0.74^{\mathrm{Aa}}\end{array}$ & $\begin{array}{l}2.41 \pm \\
0.27^{\mathrm{Bb}}\end{array}$ & $\begin{array}{l}1.18 \pm \\
0.12^{\mathrm{Aa}}\end{array}$ & $\begin{array}{l}92.45 \pm \\
7.17^{\mathrm{Aa}}\end{array}$ & $\begin{array}{l}4.06 \pm \\
0.38^{\mathrm{Bb}}\end{array}$ & $\begin{array}{l}1.56 \pm \\
0.45^{\mathrm{Aa}}\end{array}$ \\
\hline \multicolumn{8}{|c|}{$\begin{array}{l}\text { Data are presented as mean } \pm \mathrm{SD}(\mathrm{n}=9 \text { or } 12 \text { ). Different lowercase letters in the same column } \\
\text { represent significance differences at } \mathrm{P} \leq 0.05 \text { and different uppercase letters represent significant } \\
\text { differences at } \mathrm{P} \leq 0.01 \text {. The one-way ANOVA was used for statistical test. NA, Camellia oleifera new } \\
\text { afforestation; GLF, Gardenia jasminoides in a C. Oleifera low-yielding forest; LF, C. oleifera low-yielding } \\
\text { forest; GNA, G. jasminoides in C. oleifera new afforestation. } \mathrm{NH}^{4+}-\mathrm{N} \text {, soil ammonia nitrogen; } \mathrm{NO}_{3}-\mathrm{N} \text {, } \\
\text { soil nitrate nitrogen; } \mathrm{NO}_{2}-\mathrm{N} \text {, soil nitrate nitrogen; } \mathrm{AN} \text {, alkaline hydrolysable nitrogen; } \mathrm{AK} \text {, available } \\
\text { potassium; } \mathrm{AP} \text {, available phosphorus }\end{array}$} \\
\hline
\end{tabular}

Preliminary analysis of soil chemical characteristics is presented in Table 1. The total organic content (TOC), TC, and TN were highest in the $0-20 \mathrm{~cm}$ depth layer and decreased with the soil depth. The organic carbon is mainly formed by the decomposition and transformation of forest tree litter, which is the major source of organic matter accumulation on the forest soil surface. Its quantity is affected by environmental factors. Significant differences in the soil TOC, HC, SOM, TN, and TC were found among 
the different stands. GLF contained more TOC, HC, and TC compared to the other stands. GNA had the lowest TOC and SOM levels. One possible explanation was that the newly planted $G$. jasminoides and $C$. oleifera depleted a large proportion of soil TOC. The slope position did not significantly affect the soil physical indicators.

A comparison of the soil nutrient content at different soil depths revealed that the $\mathrm{NH}_{4}{ }^{+}-\mathrm{N}$ and AN levels were the lowest in the 40-60 cm depth layer, and the AP levels were the highest in the 0-20 cm depth layer (Table 2). NO3-N and AK levels did not significantly vary in different soil layers. The slope position

did not significantly affect soil chemical indicators. The highest $\mathrm{NO}_{3}-\mathrm{N}$ levels were observed in $\mathrm{LF}$, with no significant differences in $\mathrm{NO}_{2}-\mathrm{N}$ levels among different plantations. Comparison of the soil nutrient content in different forest types revealed that $\mathrm{NH}_{4}{ }^{+}-\mathrm{N}$ levels in intercropping was significantly lower than that in monoculture. We hypothesise that $G$. jasminoides and the newly planted $C$. oleifera substantially increased plant uptake of $\mathrm{NH}_{4}{ }^{+}-\mathrm{N}$ and, consequently, the nitrogen supplying capacity of the forest soil became insufficient for intercropping cultivation.

\section{Microbial diversity and richness in soil samples}

Four metrics were used for alpha diversity analysis: the observed species richness (Chao) index, abundance-based coverage estimator (ACE) index, Shannon index, and Simpson index (Gao et al. 2018; Prober et al. 2015). Alpha diversity reflects the richness and diversity of microbial community indices. The Chao index is used to estimate species richness, and the ACE index is used to indicate the number of OTUs in the soil community, therefore, the higher the score, the higher the richness. The Shannon and Simpson indices are used to characterise species diversity in a community; a high Shannon index indicates high microbial diversity. The diversity (Shannon), richness (Chao), ACE, and Simpson indices of bacterial communities are shown in Fig. 2. The species richness and number of OTUs in the soil bacterial community in GLF were significantly higher than those in LF (Fig. 2a). There were no significant differences in the determined characteristics between the soil layer depth and slope positions. This indicated that the forest type greatly affected the structural diversity of the soil bacterial community.

\section{Relationships between microbial communities in soil samples}

As shown in Fig. 3c, the number of OTUs shared by all four forest types was 1046 (56.86\% of total). The lowest number of OTUs was plotted in LF and the highest in GNA and harboured the highest number of unique OTUs (145). The number of OTUs shared by all four groups was 3,550 and took up approximately $50 \%$. The sum of OTUs in $0-20 \mathrm{~cm}$ depths was higher than in $20-40 \mathrm{~cm}$ depths. 1437 OTUs were common and accounted for $78.10 \%$ of all OTUs in different soil depths (Fig. 3a). The sum of OTUs in bottom of the hill was higher than in hillside. The endemic species diversity was the highest at the bottom of the slope (121), whereas those at the peak and hillside were essentially the same (Fig. 3b). Hence, forest type had a higher impact than the slope position and depth on OTU richness and community diversity. 


\section{Distribution of bacteria in soil samples}

At the phylum level, Proteobacteria, Chloroflexi, Acidobacteria, and Actinobacteria were dominant bacteria in all samples together, and this accounted for $88.16 \%$ of the total sequence data. Other relatively abundant phyla were GAL15, WPS-2, Verrucomicrobia, Bacteroidetes, Gemmatimonadetes, and Planctomycetes (Fig. 4a).

In different depth of soil, the phylum with the highest relative abundance, Chloroflexi, Acidobacteria, Actinobacteria, and WPS-2, were all significantly lower in the soil layers ranging from 40-60 cm to other layers, except Proteobacteria (Fig. 4b). Moreover, at different slope positions, the relative abundance of Proteobacteria was the highest in bottom and lowest in peak of the hill, while that of Acidobacteria was the highest in peak. Additionally, the relative abundances of Chloroflexi and Actinobacteria were the lowest at bottom and hillside, respectively (Fig. 4c). In different forest types, the Proteobacteria was found to be the highest at LF and the lowest at NA. Conversely, Acidobacteria and Actinobacteria were found to be the highest at NA and the lowest at LF; there were no significant differences in Chloroflexi abundance between forest types (Fig. 4d). The plantation altered the relative abundance of dominant phyla (Fig. 5) in different forest type; Acidobacteria, WPS-2 and Rokubacteria showed extremely significant differences, respectively. There were significant differences in Actinobacteria, unclassified_k_norank_d_Bacteria, and Gemmatimonadetes. There were no significant differences in the relative abundance of Proteobacteria, and additionally no significant differences in bacterial community were observed for different depths and slope positions.

\section{Beta diversity analysis of soil samples}

Distances were used to identify the variation of soil microbial communities that influence the soil microbial community in different soil samples (Fig. 6). Samples were divided into different groups based on forest type, slope position, and difference of soil depth. When all tested samples were divided into three groups according to the depth, the $40-60 \mathrm{~cm}$ was clearly distinct from $0-20 \mathrm{~cm}$ and $20-40 \mathrm{~cm}$ (Fig. 6a, b). While samples were separated into peak, hillside, and bottom groups, the groups did not form distinct clusters based on Bray-Curtis distance of PCoA analysis (Fig. 6c, d). Similarly, four groups at different forest type were not distinct, indicating no difference between the tested groups in bacterial community structure. (Fig. 6e, f).

\section{Relationships between soil microbial communities and soil physicochemical properties}

At the level of phylum, redundancy analysis (RDA) analysis of soil bacterial communities and environmental factors was performed with the depth, slope position, and forest types as research targets. The results of this analysis are shown in Fig. 7. RDA clearly showed the effects of different environmental factors on soil microbial communities. We concluded that AK, $\mathrm{pH}$ and $\mathrm{AN}$ were key environmental factors 
for affecting bacterial communities of soil in the forest type group; $\mathrm{AN}, \mathrm{SMC}, \mathrm{pH}$, and $\mathrm{AK}$ were key environmental factors in depth and slope position groups.

Further analysis of correlations between environmental factors and the top 20 most abundant bacterial communities at the phylum level were based on the Spearman rank correlation coefficient. Results revealed correlations between soil physical and chemical properties and bacterial communities in soil systems (Fig. 8). There was a significant positive correlation between $\mathrm{pH}$ and Acidobacteria, Nitrospirae, Elusimicrobia, and Rokubacteria $(p<0.01)$ and positive correlation with Dependentiae, Gemmatimnadetes, and GAL15 $(p<0.05)$. Meanwhile, some phyla were significantly correlated with concentration of available nutrients, concentrations of the soil humus content $(\mathrm{HC})$ were significantly positive correlated to Elusimicrobia, Dependentiae, Acidobacteria, and Cyanobacteria $(p<0.05)$. Available nitrogen (AN) was significantly positively correlated with Dependentiae, FCPU426, and Acidobacteria ( $p<$ $0.01)$, while positively correlated with Gemmatimnadetes, Nitrospirae, and Elusimicrobia $(p<0.05)$. Additionally, Dependentiae and Acidobacteria were positively correlated to most environmental factors in this study, while the bacterial phylum Cyanobacteria and Elusimicrobia were significantly negatively correlated to $\mathrm{NO}_{3}-\mathrm{N}, E C$, and TDS $(\mathrm{p}<0.05)$. In conclusion, environmental factors had a potential impact on the bacterial microbial community and created differences in their abundance.

\section{Discussion}

Understanding impacts of forestry practices on the soil microbiota is important for achieving sustainable forestry. Therefore, the study of soil nutrient characteristics and soil microbial community characteristics of $C$. oleifera would inform soil management of this species. Accordingly, in the current study, the analysis of soil physical and chemical properties revealed that the TOC, TC, and TN were the highest in the 0-20 cm soil layer and decreased with depth. SOC, HC, and TOC were higher in G. jasminoides $+C$. oleifera low-yielding forest than in other stands. Few effects of slope position on the soil physical and chemical properties were detected. Further, based on high-throughput sequencing, Proteobacteria and Acidobacteria were major bacterial phyla in soil communities identified in the results of our study, which were consistent with findings of previous studies. (Li et al. 2018, 2019).

The results in the current study suggested that $G$. jasminoides planted together with $C$. oleifera influenced the composition of soil bacteria. Further, bacterial communities in the soil were mostly influenced by the combination of $G$. jasminoides when combined with $C$. oleifera. Slope position also significantly affected the soil bacterial community composition.

Proteobacteria and Acidobacteria are the primary bacterial taxa in soil associated with the decomposition of SOM; the change in SOM content is highly correlated with the abundance of Proteobacteria (Fierer et al. 2007; Banerjee et al., 2016). The abundance of Proteobacteria is the largest in disturbed forest soil (Noble et al. 2020), implying their significance in carbon turnover. A previous study has demonstrated that Acidobacteria diversity is inversely related to soil depth and the abundance of Acidobacteria is the largest in unmanaged forest soil (Kuske et al. 2002; Sheng et al. 2019), which was largely confirmed in the 
current study. This may be attributed to the Acidobacteria oligotrophic nature or ecological K-strategy (Ward et al., 2009; Kielak et al., 2016a).

The research from our study confirmed that plantation altered the relative abundance of dominant phyla, and no significant differences in bacterial community were observed for different depths and slope positions. These observations suggested that different forest substructures affect the soil ecological environment. A study on the effect of leguminous supplementation on the resilience of soil microbial community and nutrient content in Chinese fir plantations has shown that functional plant supplementation significantly increases the diversity and richness of soil microbes, accelerates the transformation and absorption of soil nutrients, and promotes the growth of Chinese fir (Zhang et al. 2020). Hence, complex bacterial community structure increases soil resistance to adverse environmental factors and is important for the protection of the soil ecosystems. Soil physical and chemical properties and microorganisms, as key components of the soil ecosystem, play an irreplaceable role in the ecosystem.

\section{Conclusions}

Cultivating $G$. jasminoides together with $C$. oleifera is a promising method for plant growth promotion. It increases the soil fertility and microbial diversity and promotes the network structure and growth of key microbial organisms, thus improving the potential ecosystem function on $C$. oleifera plantations. These beneficial effects were more obvious when different forest types were considered, and less apparent so when the soil depth and slope position were analysed. When $G$. jasminoides was introduced into $C$. oleifera stand, it significantly affected microbial communities as well as physico-chemical properties. Specifically, SOC, HC, and TOC were higher in G. jasminoides with $C$. oleifera low-yielding forest than in other stands. As revealed by $\mathrm{RDA}, \mathrm{AK}, \mathrm{pH}$, and $\mathrm{AN}$ were the principal drivers shaping the soil microbial structure, and microbial composition was significantly influenced by the land use change, rather than by depth and slope position. Compared with Acidobacteria, relatively little attention has been paid to the Parcubacteria phylum. According to several studies, Parcubacteria has shown to diversify carbon source utilisation capacity and suppress plant diseases (Danczak et al. 2017). The specific bacterial taxa in soils of $C$. oleifera plantations warrant further investigation. Furthermore, litter of multiple tree species improves soil structure and promotes the build-up of diverse microbial communities compared to homogenous litter. Replacing monocultures with mixed-species stands is therefore a promising approach for maintaining soil biodiversity and stability and improving nutrient content of the soil.

\section{Declarations}

Funding: The study was in part funded by the Key Innovation Team of Changde: Deep Processing of Plant Products (Changde Talent Office [2018] No. 1) and Research Foundation of Education Bureau of Hunan Province, China (Project No. 20A360).

Conflicts of interest/ Competing interests: The authors declare no conflict of interest. 
Availability of data and material: The data that support the findings of this study are available at Majorbio Cloud Platform (www.majorbio.com) but restrictions apply to the availability of these data, which were used under licence for the current study, and therefore are not publicly available. Data are however available from the authors upon reasonable request and with permission of Majorbio Cloud Platform.

Code availability: Not applicable.

\section{Authors' contributions}

Methodology: Jiyun She conceived and designed the experiments;

Investigation, Formal analysis, Writing - original draft: Yun Wang and Peng Xie;

Investigation: Aihua Deng;

Writing - original draft: Shaogang Fan;

Writing - review \& editing: All authors read and approved the final version of the manuscript.

Ethical approval: Not applicable.

Consent to participate: Not applicable.

Consent for publication: Not applicable.

\section{References}

1. Banerjee S, Kirkby CA, Schmutter D, Bissett A, Kirkegaard JA, Richardson AE (2016) Network analysis reveals functional redundancy and keystone taxa amongst bacterial and fungal communities during organic matter decomposition in an arable soil. Soil Biol Biochem 97:188-198. https://doi.org/10.1016/j.soilbio.2016.03.017

2. Danczak RE, Johnston MD, Kenah C, Slattery M, Wrighton KC, Wilkins MJ (2017) Members of the Candidate Phyla Radiation are functionally differentiated by carbon- and nitrogen-cycling capabilities. Microbiome 5:112. https://doi.org/10.1186/s40168-017-0331-1

3. Ding X, Zhang B, Lü X, Wang J, Horwath WR (2017) Parent material and conifer biome influence microbial residue accumulation in forest soils. Soil Biol Biochem 107:1-9. https://doi.org/10.1016/j.soilbio.2016.12.020

4. Dollinger J, Jose S (2018) Agroforestry for soil health. Agroforest Syst 92:213-219. https://doi.org/10.1007/s10457-018-0223-9

5. Dunn RM, Mikola J, Bol R, Bardgett RD (2006) Influence of microbial activity on plant-microbial competition for organic and inorganic nitrogen. Plant Soil 289:321-334. https://doi.org/10.1007/s11104-006-9142-z 
6. Fierer N, Bradford MA, Jackson RB (2007) Toward an ecological classification of soil bacteria. Ecology 88:1354-1364. https://doi.org/10.1890/05-1839

7. Gao X, Jia R, Xie L, Kuang L, Feng L, Wan C (2018) A study of the correlation between obesity and intestinal flora in school-age children. Sci Rep 8:14511. https://doi.org/10.1038/s41598-018-32730-6

8. Goss-Souza D, Mendes LW, Borges CD, Baretta D, Tsai SM, Rodrigues JLM (2017) Soil microbial community dynamics and assembly under long-term land use change. FEMS Microbiol Ecol 93:fix109. https://doi.org/10.1093/femsec/fix109

9. Hermans SM, Buckley HL, Case BS, Curran-Cournane F, Taylor M, Lear G (2017) Bacteria as emerging indicators of soil condition. Appl Environ Microbiol 83:e02826-e02816.

https://doi.org/10.1128/AEM.02826-16

10. Hermans SM, Buckley HL, Case BS, Curran-Cournane F, Taylor M, Lear G (2020) Using soil bacterial communities to predict physico-chemical variables and soil quality. Microbiome 8:79. https://doi.org/10.1186/s40168-020-00858-1

11. Horner A, Browett SS, Antwis RE (2019) Mixed-cropping between field pea varieties alters root bacterial and fungal communities. Sci Rep 9:16953. https://doi.org/10.1038/s41598-019-53342-8

12. Jiao S, Chen W, Wang J, Du N, Li Q, Wei G (2018) Soil microbiomes with distinct assemblies through vertical soil profiles drive the cycling of multiple nutrients in reforested ecosystems. Microbiome 6:146. https://doi.org/10.1186/s40168-018-0526-0

13. Khan S, Mulvaney RL, Mulvaney CS (1997) Accelerated diffusion methods for inorganic-nitrogen analysis of soil extracts and water. Soil Sci Soc Am J 61:936-942. https://doi.org/10.2136/sssaj1997.03615995006100030032x

14. Kielak AM, Barreto CC, Kowalchuk GA, van Veen JA, Kuramae EE (2016) The ecology of Acidobacteria: moving beyond genes and genomes. Front Microbiol 7:744 https://doi.org/10.3389/fmicb.2016.00744

15. Krishnamoorthy U, Muscato TV, Sniffen CJ, Van Soest PJ (1982) Nitrogen fractions in selected feedstuffs. J Dairy Sci 65:217-225 https://doi.org/10.3168/jds.S0022-0302(82)82180-2

16. Kroon J, Bergsten U, Sonesson J (2019) Increasing production value in Scots pine plantation through mixing with lodgepole pine. Scan J For Res 34:689-698.

https://doi.org/10.1080/02827581.2019.1695909

17. Kuske CR, Ticknor LO, Miller ME, Dunbar JM, Davis JA, Barns SM, Belnap J (2002) Comparison of soil bacterial communities in rhizospheres of three plant species and the interspaces in an arid grassland. Appl Environ Microbiol 68:1854-1863. https://doi.org/10.1128/aem.68.4.18541863.2002

18. Li J, Wu Z, Yuan J (2019) Impact of agro-farming activities on microbial diversity of acidic red soils in a Camellia oleifera forest. Rev Bras Ciênc Solo 43:e0190044. https://doi.org/10.1590/18069657rbcs20190044

19. Li R, Kan S, Zhu M, Chen J, Ai X, Chen Z, Zhang J, Ai Y (2018) Effect of different vegetation restoration types on fundamental parameters, structural characteristics and the soil quality index of 
artificial soil. Soil Till Res 184:11-23. https://doi.org/ 10.1016/j.still.2018.06.010

20. Lane DJ (1991) 16S/23S rRNA Sequencing. Nucleic Acid Techniques in Bacterial Systematics. https://doi.org/ 10.4135/9781446279281.n7

21. Liu Z, Jia G, Yu X (2020) Variation of water uptake in degradation agroforestry shelterbelts on the North China Plain. Agric Ecosys Environ 287:106697. https://doi.org/10.1016/j.agee.2019.106697

22. Lu RK (1999) Soil and agro-chemistry analytical methods. Agriculture Science and Technology Press of China, Beijing

23. Lu W, Shen $X$, Chen $Y$ (2019) Effects of intercropping peanut on soil nutrient status and microbial activity within young Camellia oleifera plantation. Comm Soil Sci Plant Anal 50:1232-1238. https://doi.org/10.1080/00103624.2019.1614600

24. Mitchell RJ, Hester AJ, Campbell CD, Chapman SJ, Cameron CM, Hewison RL, Potts JM (2010) Is vegetation composition or soil chemistry the best predictor of the soil microbial community? Plant Soil 333:417-430. http://dx.doi.org/10.1007/s11104-010-0357-7

25. Mosquera-Losada MR, Santiago-Freijanes JJ, Rois-Díaz M, Moreno G, den Herder M, Aldrey-Vázquez JA, Ferreiro-Domínguez N, Pantera A, Pisanelli A, Rigueiro-Rodríguez A (2018) Agroforestry in Europe: A land management policy tool to combat climate change. Land Use Policy 78:603-613. https://doi.org/10.1016/j.landusepol.2018.06.052

26. Müller DB, Vogel C, Bai Y, Vorholt JA (2016) The plant microbiota: systems-level insights and perspectives. Annu Rev Genet 50:211-234. https://doi.org/10.1146/annurev-genet-120215-034952

27. Nacke H, Goldmann K, Schöning I, Pfeiffer B, Kaiser K, Castillo-Villamizar GA, Schrumpf M, Buscot F, Daniel R, Wubet $T$ (2016) Fine spatial scale variation of soil microbial communities under European beech and Norway spruce. Front Microbiol 7:2067. https://doi.org/10.3389/fmicb.2016.02067

28. Noble AS, Noe S, Clearwater MJ, Lee CK (2020) A core phyllosphere microbiome exists across distant populations of a tree species indigenous to New Zealand. PLoS One 15:e0237079. https://doi.org/10.1371/journal.pone.0237079

29. Prober SM, Leff JW, Bates ST et al (2015) Plant diversity predicts beta but not alpha diversity of soil microbes across grasslands worldwide. Ecol Lett 18:85-95. https://doi.org/10.1111/ele.12381

30. Quandt A, Neufeldt H, McCabe JT (2019) Building livelihood resilience: what role does agroforestry play? Clim Dev 11:485-500. https://doi.org/10.1080/17565529.2018.1447903

31. Schulz E (2002) Influence of extreme management on decomposable soil organic matter pool. Arch Agron Soil Sci 48:101-105. https://doi.org/10.1080/03650340214166

32. Sheng Y, Cong J, Lu H, Yan L, Liu Q, Li D, Zhang Y (2019) Broad-leaved forest types affect soil fungal community structure and soil organic carbon contents. MicrobiologyOpen 8:e874. https://doi.org/10.1002/mbo3.874

33. Six J, Bossuyt H, Degryze S, Denef K (2004) A history of research on the link between (micro)aggregates, soil biota, and soil organic matter dynamics. Soil Till Res 79:7-31. https://doi.org/10.1016/j.still.2004.03.008 
34. Tobias-Hünefeldt SP, Wing SR, Espinel-Velasco N, Baltar F, Morales SE (2019) Depth and location influence prokaryotic and eukaryotic microbial community structure in New Zealand fjords. Sci Total Environ 693:133507. https://doi.org/10.1016/j.scitotenv.2019.07.313

35. Tu J, Chen J, Zhou J, Ai W, Chen L (2019) Plantation quality assessment of Camellia oleifera in midsubtropical China. Soil Till Res 186:249-258. https://doi.org/10.1016/j.still.2018.10.023

36. van der Heijden MG, Streitwolf-Engel R, Riedl R, Siegrist S, Neudecker A, Ineichen K, Boller T, Wiemken A, Sanders IR (2006) The mycorrhizal contribution to plant productivity, plant nutrition and soil structure in experimental grassland. New Phytol 172:739-752. https://doi.org/10.1111/j.14698137.2006.01862.x

37. Wang J, Soininen J, Zhang Y, Wang B, Yang X, Shen J (2011) Contrasting patterns in elevational diversity between microorganisms and macroorganisms. J Biogeogr 38:595-603. https://doi.org/10.1111/j.1365-2699.2010.02423.x

38. Ward NL, Challacombe JF, Janssen PH, Henrissat B, Coutinho PM, Wu M et al (2009) Three genomes from the phylum Acidobacteria provide insight into the lifestyles of these microorganisms in soils. Appl Environ Microbiol 75:2046-2056. https://doi.org/10.1128/AEM.02294-08

39. Wu F, Li J, Chen Y, Zhang L, Zhang Y, Wang S, Shi X, Li L, Liang J (2019) Effects of phosphate solubilizing bacteria on the growth, photosynthesis, and nutrient uptake of Camellia oleifera Abel. Forests 10:348. https://doi.org/10.3390/f10040348

40. Xiao S, He Y (2019) Application of near-infrared spectroscopy and multiple spectral algorithms to explore the effect of soil particle sizes on soil nitrogen detection. Molecules 24:2486. https://doi.org/10.3390/molecules24132486

41. Zhalnina K, Dias R, Dörr de Quadros P, Davis-Richardson A, Camargo FAO, Clark IM, McGrath SP, Hirsch PR, Triplett EW (2015) Soil pH determines microbial diversity and composition in the park grass experiment. Microb Ecol 69:395-406. https://doi.org/10.1007/s00248-014-0530-2

42. Zhang P, Cui Z, Guo M, Xi R (2020) Characteristics of the soil microbial community in the forestland of camellia oleifera. PeerJ 8:9117. https://doi.org/10.7717/peerj.9117

43. Zhang Y, Hou L, Li Z, Zhao D, Song L, Shao G, Ai JJ, Sun Q (2020) Leguminous supplementation increases the resilience of soil microbial community and nutrients in Chinese fir plantations. Sci Total Environ 703:134917. https://doi.org/10.1016/j.scitotenv.2019.134917

\section{Figures}




\section{a}

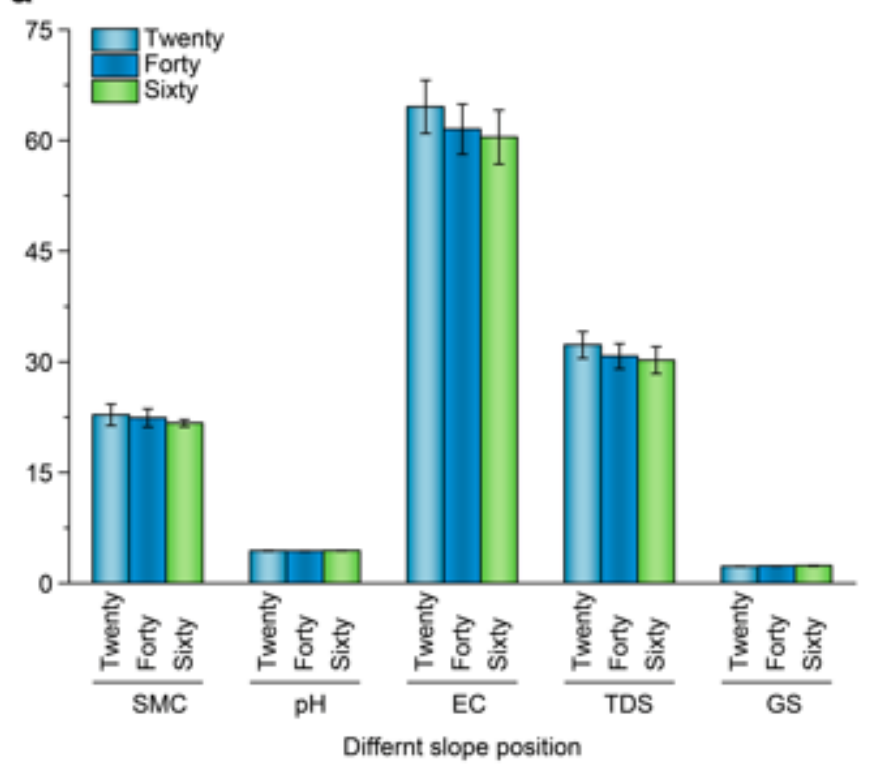

C

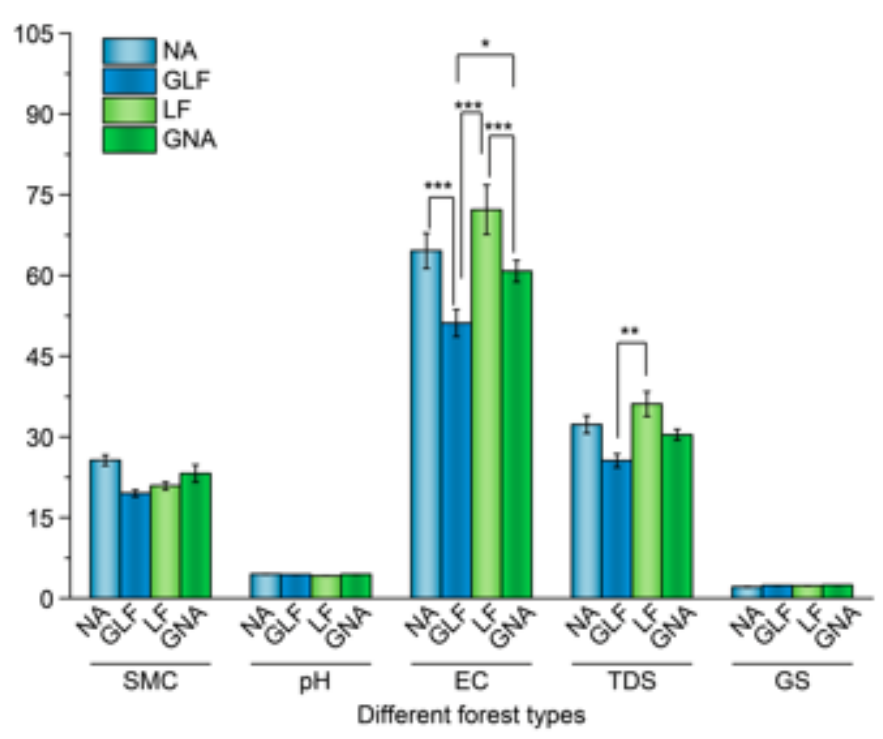

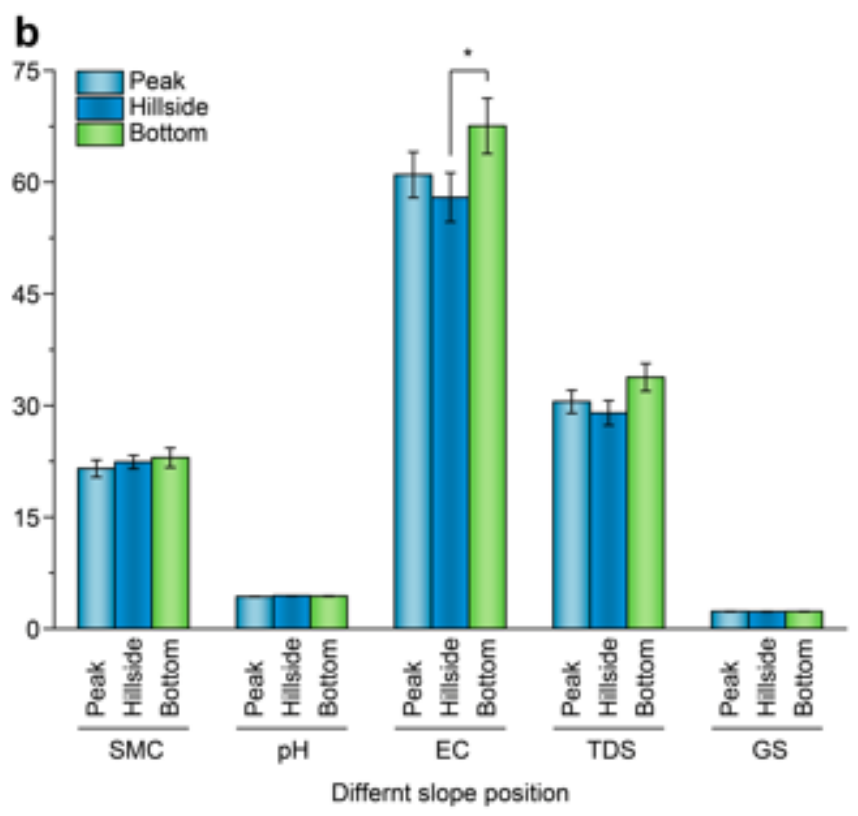

\section{Figure 1}

Physical properties of the soil The soil was sampled at different depths (a), at different slope positions (b), and in different forest types (c). SMC (\%), soil moisture content; EC ( $\mu \mathrm{s} \cdot \mathrm{cm}-1)$, electric conductivity; TDS ( $\mu \mathrm{g} \cdot \mathrm{L}-1)$, total dissolved solid; GS $(\mathrm{g} \cdot \mathrm{cm}-3)$, specific soil weight. Forest types: NA, Camellia oleifera new afforestation; GLF, Gardenia jasminoides in a C. oleifera low-yielding forest; LF, C. oleifera lowyielding forest; GNA, G. jasminoides in C. oleifera new afforestation. Twenty, soil layer at $0-20 \mathrm{~cm}$ depth; Forty, soil layer at $20-40 \mathrm{~cm}$ depth; Sixty, soil layer at $40-60 \mathrm{~cm}$ depth. The data are shown as mean \pm SD. $(n=9$ or $12 ; * P<0.05, \star * P<0.01, * \star \star P<0.001)$. Statistical analysis was performed using the one-way analysis of variance, and Tukey's multiple comparison test was used to correct for multiple comparisons 

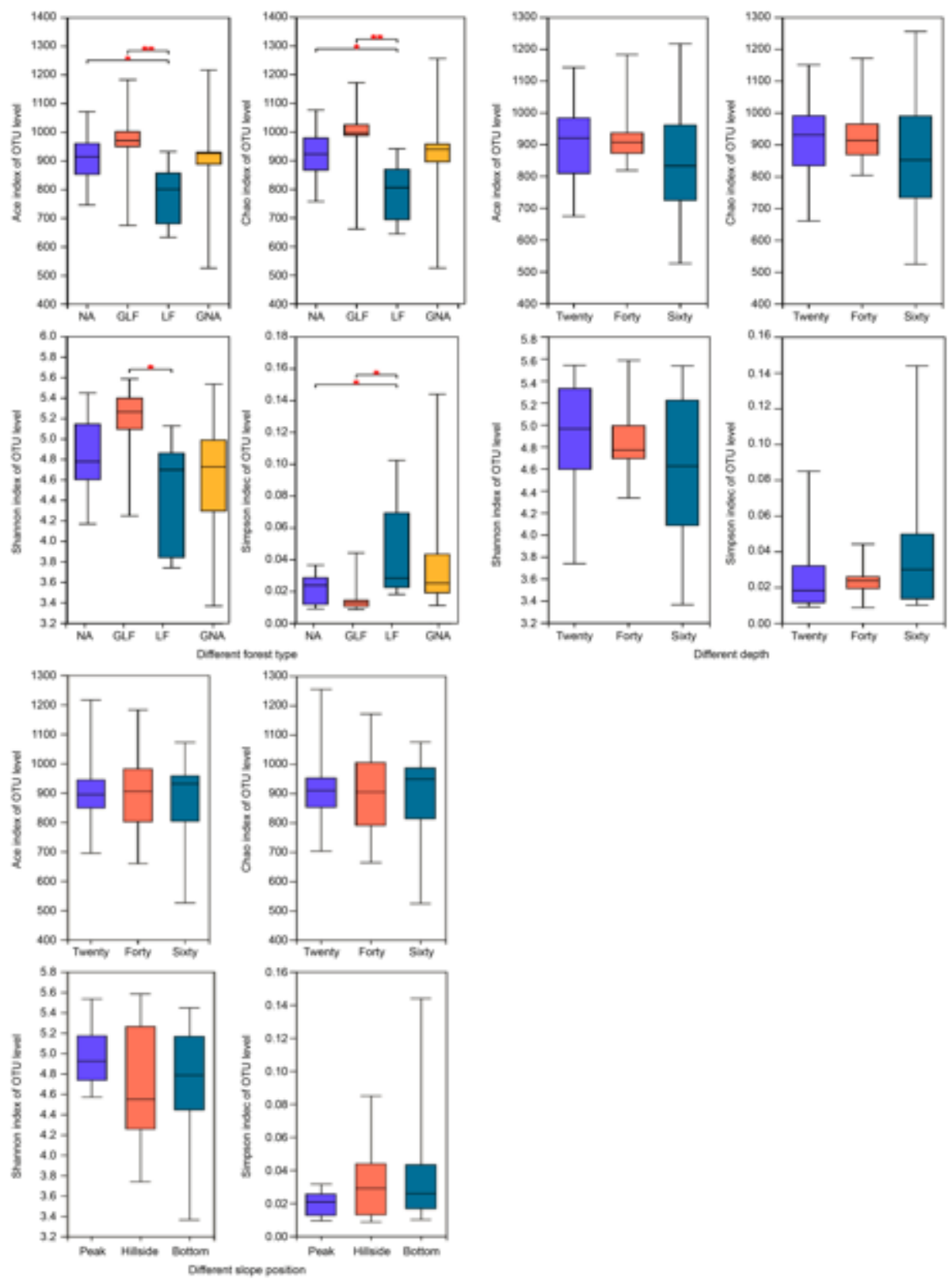

\section{Figure 2}

General patterns of microbial alpha diversity Boxplot of alpha diversity indices, including community richness (Ace, Chao) and diversity (Shannon, Simpson), varied among each group. Microbial alpha diversity in the soils sampled in different forest types (a), at different depths (b), and at different slope positions (c). NA, Camellia oleifera new afforestation; GLF, Gardenia jasminoides in a C. oleifera lowyielding forest; LF, C. oleifera low-yielding forest; GNA, G. jasminoides in C. oleifera new afforestation. Twenty, soil layer at 0-20 cm depth; Forty, soil layer at 20-40 cm depth; Sixty, soil layer at $40-60 \mathrm{~cm}$ depth. OUT, operational taxonomic unit; ACE, abundance-based coverage estimator. The data are represented as a box-and-whiskers plot representing median values with interquartile ranges. Different colours indicate different sampling campaigns, sampling locations $\left(n=9\right.$ or $12 ;{ }^{*} P<0.05,{ }^{\star \star} P<0.01$, [Student's t-test for estimator]) 

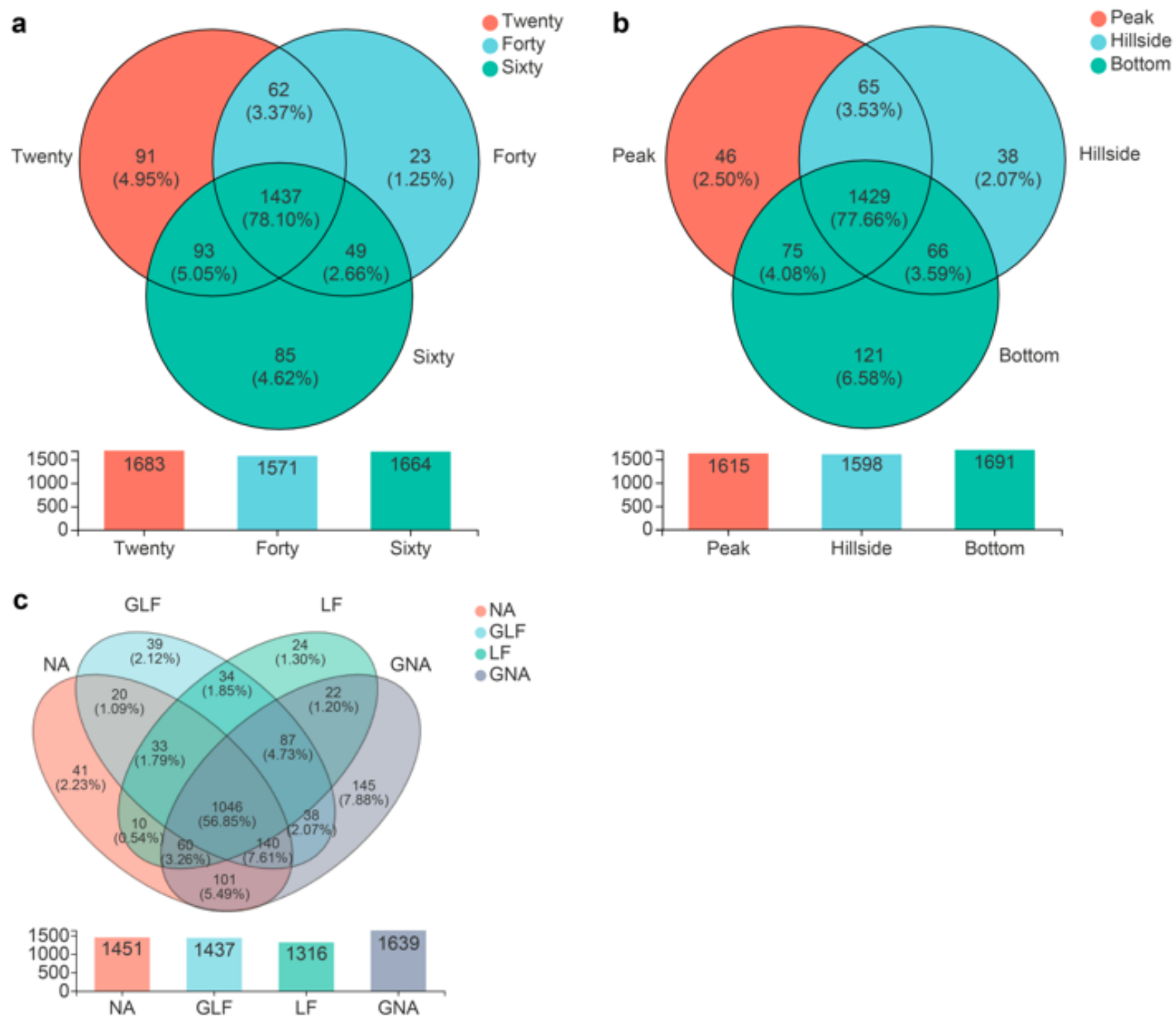

\section{Figure 3}

Venn diagram analysis of soil bacterial community composition at the operational taxonomic unit (OTU) level Comparisons of the OTU numbers (a) at different depths, (b) at different slope positions, and (c) in different forest types are shown ( $n=9$ or 12). The numbers indicate the number of OTUs; the percentage values indicate the percentage of the total OTUs. NA, Camellia oleifera new afforestation; GLF, Gardenia jasminoides in a C. oleifera low-yielding forest; LF, C. oleifera low-yielding forest; GNA, G. jasminoides in C. oleifera new afforestation. Twenty, soil layer at 0-20 cm depth; Forty, soil layer at 20-40 cm depth; Sixty, soil layer at 40-60 cm depth. Overlaps and non-overlaps indicate shared and exclusive OTUs under different samples; the bar graphs indicate the number of total species in each group 

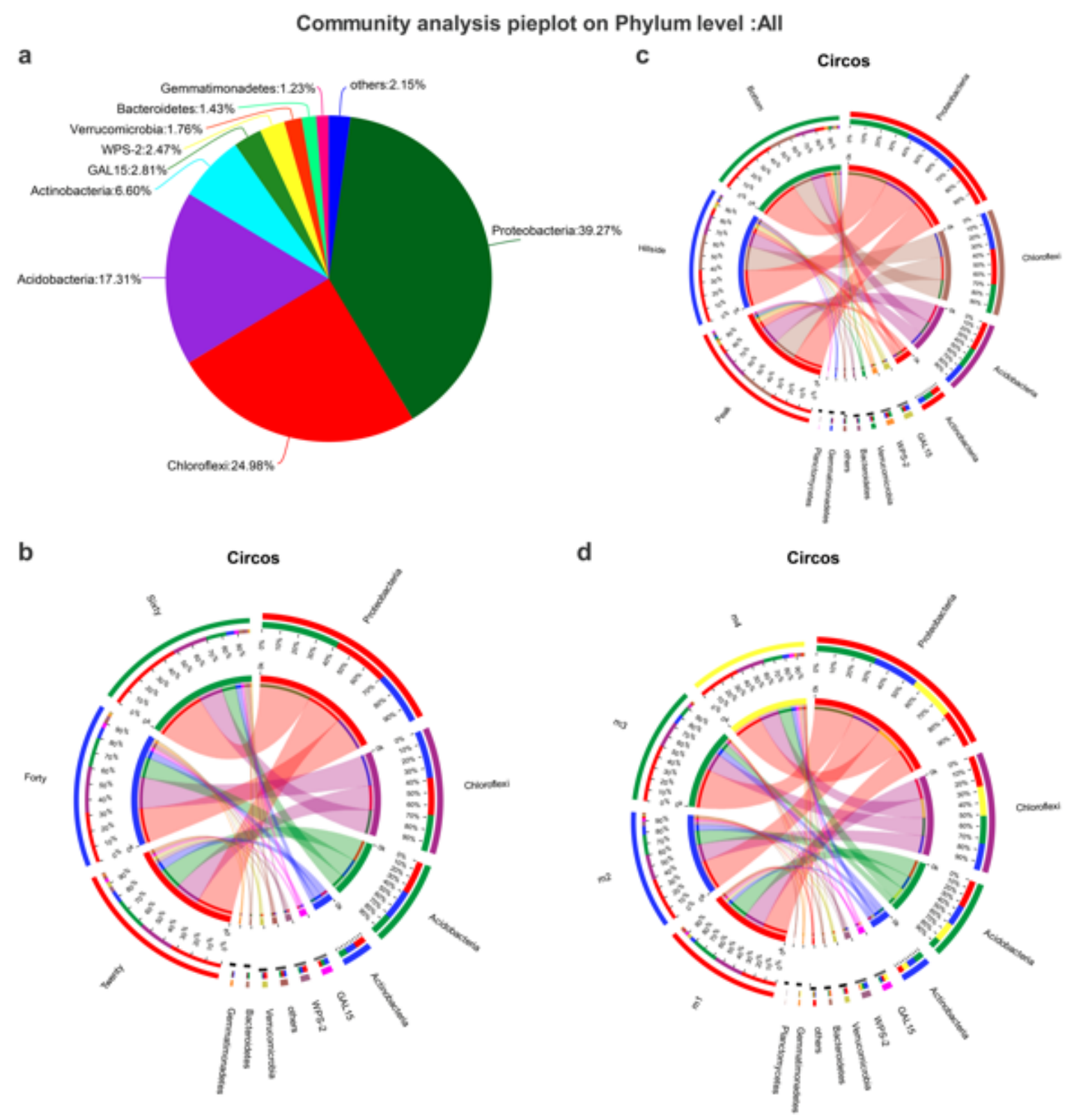

\section{Figure 4}

Relative abundance of soil bacteria at the phylum level The pie chart presents the percentage of species, and the colours designate species (a). In the circos plot, the colours in the left semi-circle represent the species composition, and the outermost circles represent the grouping information. The colours of the inner circles represent species, and the length represents the relative abundance of the species; the right semi-circle indicates the distribution proportions of species in different samples at the taxonomic level for that cluster, the colours of outermost circles represent species, the colours of the inner circles represent grouping information, and the length represents the fraction of that species for that cluster $(b-d)$. The soil was sampled (b) at different depths, (c) at different slope positions, and (d) in different forest types $(n=9$ or 12). m1 (NA), Camellia oleifera new afforestation; m2 (GLF), Gardenia jasminoides in a C. oleifera low-yielding forest; m3 (LF), C. oleifera low-yielding forest; m4 (GNA), G. jasminoides in C. oleifera 
new afforestation. Twenty, soil layer at 0-20 cm depth; Forty, soil layer at $20-40 \mathrm{~cm}$ depth; Sixty, soil layer at 40-60 cm depth. Here, 'others' indicate taxa with a maximum abundance of $<0.5 \%$ in any sample
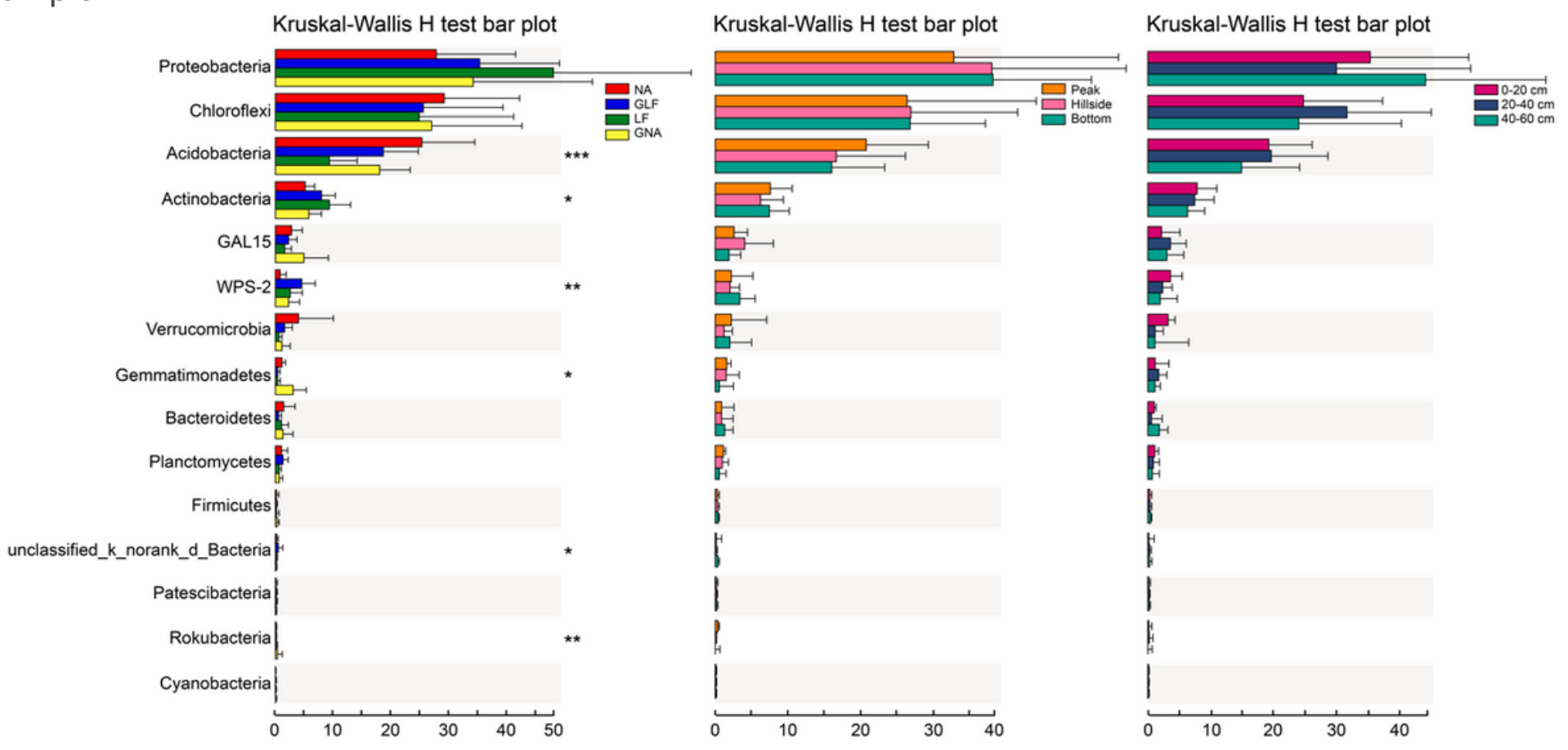

\section{Figure 5}

Microbial community diversity in different forest types (a), at different slope positions (b), and at different depths (c) via Kruskal-Wallis $\mathrm{H}$ test bar plot The image represents the difference between proportions in 95\% confidence intervals. 'Unclassified' includes all unclassified species obtained directly from database via sequence alignment. The $X$-axis represents the average relative abundance of different species, the $Y$ axis represents the species, and different colours indicate the different groups. NA, Camellia oleifera new afforestation; GLF, Gardenia jasminoides in a C. oleifera low-yielding forest; LF, C. oleifera low-yielding forest; GNA, G. jasminoides in C. oleifera new afforestation. Twenty, soil layer at 0-20 cm depth; Forty, soil layer at 20-40 cm depth; Sixty, soil layer at 40-60 cm depth. $n=9$ or 12 ; ${ }^{P}<0.05, * * P<0.01$ 
a

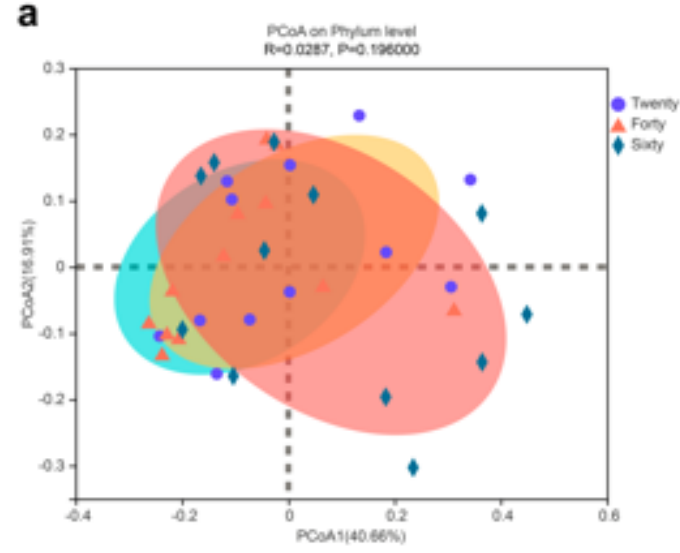

C

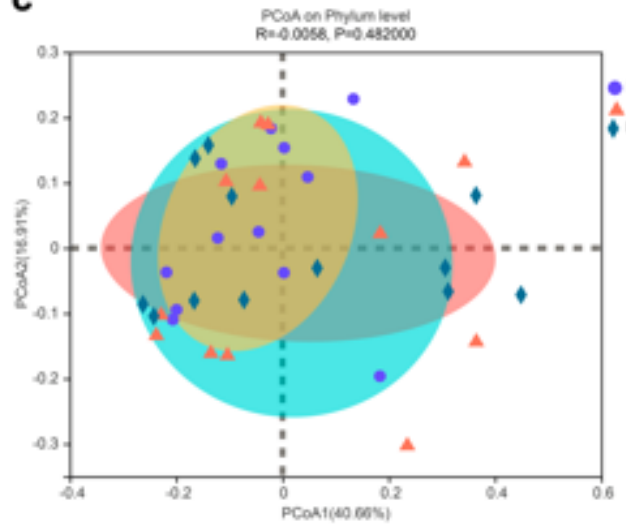

e

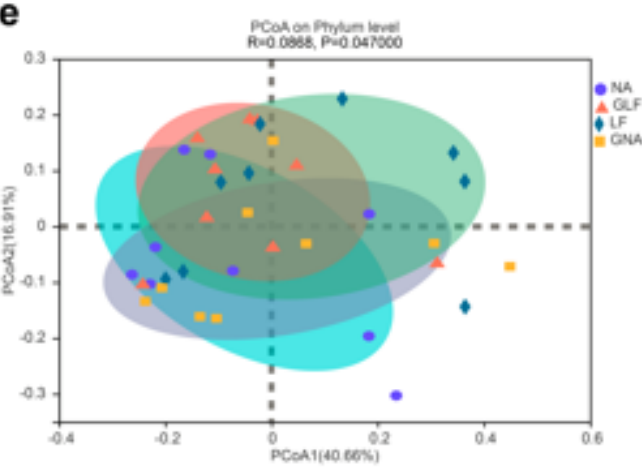

b

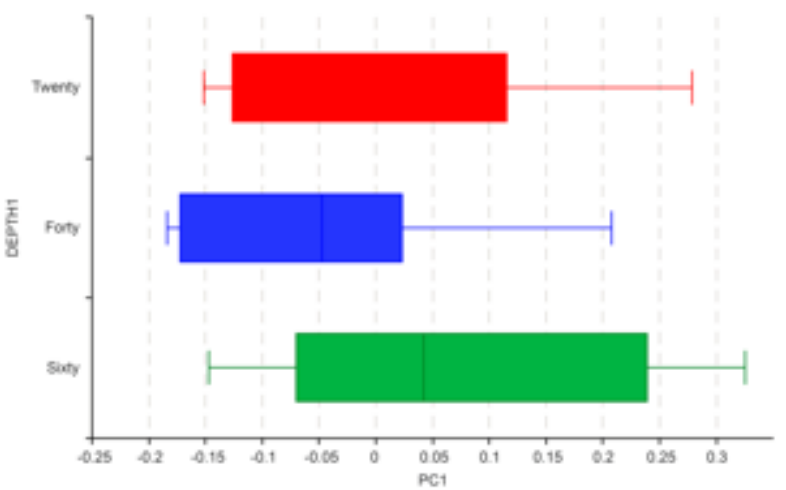

d

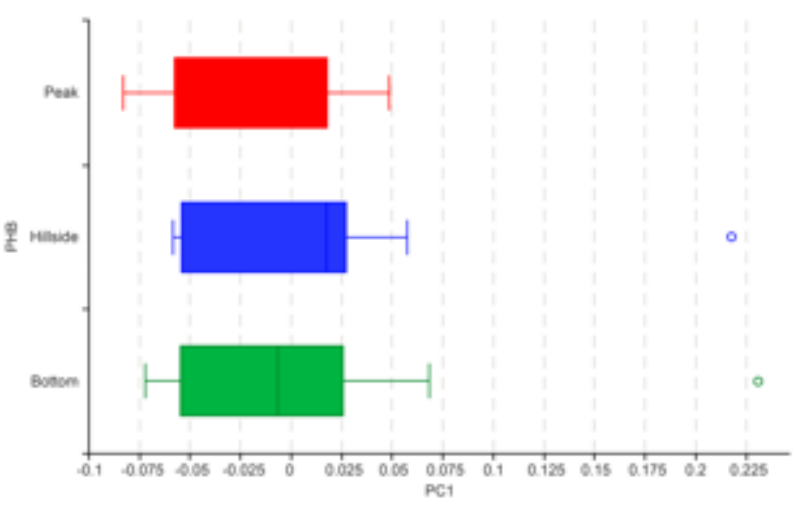

$\mathbf{f}$

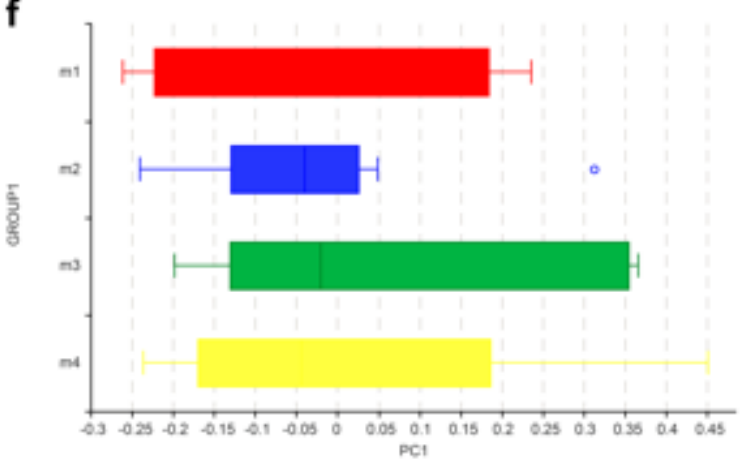

\section{Figure 6}

Principal coordinate analysis (PCOA) of the soil bacterial community composition as affected by forest type (a), depth (b), and slope position (c) PCoA is based on the Bray-Curtis distance. The same colour points belong to the same group, and the same soil group points are marked by ellipses. Abscissa represents the first principal component, ordinate represents the second principal component, and the percentage represents the contribution of the principal component to the sample difference. Box plots represent the discrete distribution of different groups of samples along the PCoA1 axis and the colour represents different sample groups. Values of R2 and P were calculated using analysis of similarities. NA, Camellia oleifera new afforestation; GLF, Gardenia jasminoides in a C. oleifera low-yielding forest; LF, C. oleifera low-yielding forest; GNA, G. jasminoides in C. oleifera new afforestation. Twenty, soil layer at 0$20 \mathrm{~cm}$ depth; Forty, soil layer at 20-40 cm depth; Sixty, soil layer at 40-60 cm depth 

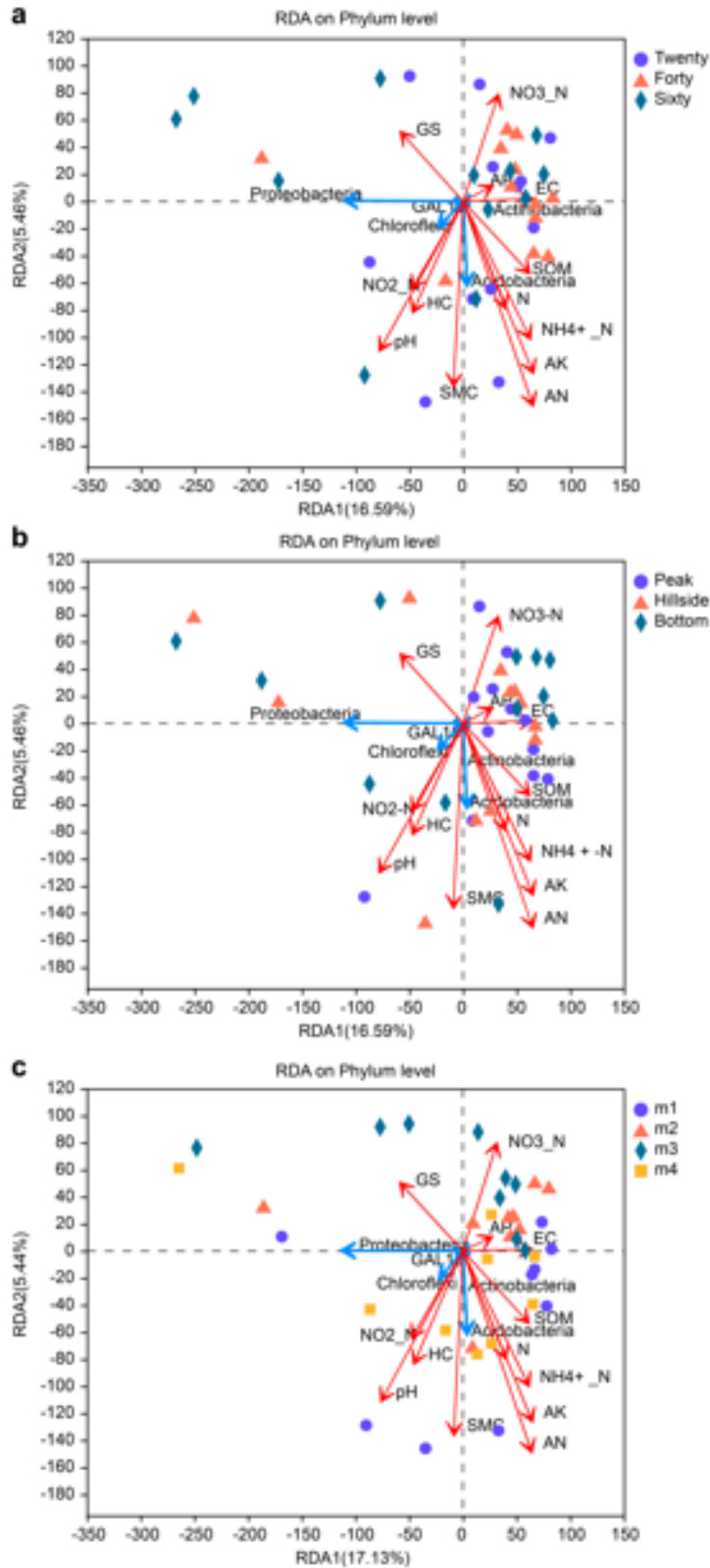

\section{Figure 7}

Redundancy analysis (RDA) illustrating relationships between soil physicochemical properties and bacterial community diversity and explains the correlation between environmental factors and soil microbes The same shape and colour represent the same group. The red arrow indicates the quantitative environmental factor, and the length of the environmental factor arrow represents the degree of influence of the environmental factor on the species data (interpretation). The longer the arrow, the greater the influence. The angle between the environmental factor axis indicates the positive and negative correlations (the parameters mean positive correlation, the obtuse angle mean negative correlation, and right angle means no correlation). Projection from the sample point to the arrow of the quantitative environmental factor, the distance from projected points to the origin indicates the relative effect of the microbial communities and environmental factors. m1(NA), Camellia oleifera new afforestation; 
m2(GLF), Gardenia jasminoides in C. oleifera low-yielding forest; m3(LF), C. oleifera low-yielding forest; m4(GNA), G. jasminoides in C. oleifera new afforestation. Twenty, soil layer at 0-20 cm depth; Forty, soil layer at 20-40 cm depth; Sixty, soil layer at 40-60 cm depth

\section{Spearman correlation heatmap}

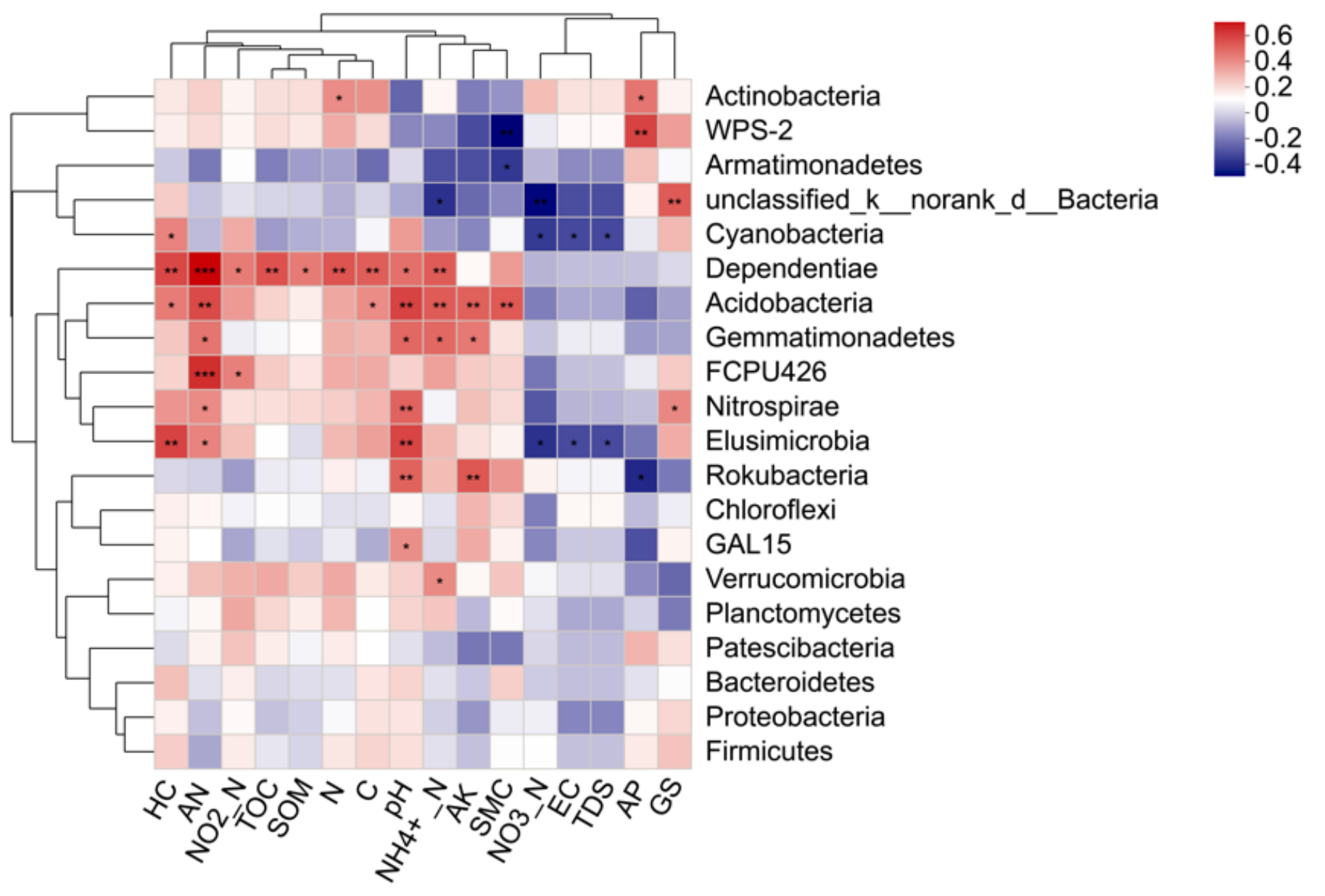

\section{Figure 8}

Correlations between environmental factors and the top 20 most abundant bacterial communities at phylum level The $X$ and $Y$ axes are horizontal and vertical angular environmental factors (species composition), respectively. $\mathrm{HC}$, humus content; GS, specific gravity of solid particles; AP, available phosphorus; TOC, total organic carbon; SOM, soil organic matter; N, soil total nitrogen; C, soil total carbon; NO3-N, nitrate nitrogen; EC, soil electric conductivity; TDS, total dissolved solid; AK, available potassium; $\mathrm{SMC}$, soil moisture capacity; $\mathrm{AN}$, available nitrogen; $\mathrm{NO2}-\mathrm{N}$, nitrite nitrogen; $\mathrm{NH} 4+\mathrm{N}$, ammonium nitrogen. The red shades represent positive correlations and blue shades represent negative correlations. Darker shades represent stronger correlations. $\left(n=9\right.$ or $12 ;{ }^{*} P<0.05, \star \star P<0.01, \star \star \star P<0.001$.) 